\title{
BIOLOGICAL WASTEWATER TREATMENT IN CONTEXT OF CIRCULAR ECONOMY
}

\author{
Dzihora Y. $^{1,2}$, Stolyarenko H. ${ }^{1}$ \\ ${ }^{1}$ Cherkasy state technological university, Cherkasy, Ukraine \\ ${ }^{2}$ Norwegian university of life sciences, Ås, Norway
}

DOI: https://doi.org/10.20535/2218-930012021232378

With the beginning of the Anthropocene epoch, nature is facing a lot of environmental problems that drastically increased in the last century. At the current rate of resource consumption, soon nature will lose the ability for self-restoration. In order to avoid the inevitable consequences of resources exploitation, new approaches should be developed in all areas of human life. Linear economy concepts that were utilized for a long time and were based on the use and disposal of each separate resource depending on the purpose are not sufficient anymore. A more holistic approach should be applied to overcome the challenges that we are facing now. The application of circular economy concepts for wastewater treatment facilities has a great potential to enhance the sustainability of water management. This paper will focus on circular economy concepts applied for modern pilot installation that combines biological treatment and membrane separation and discusses the potential for full-scale implementation. Since the pilot plant was operated without any chemicals addition it eases the use of the waste sludge that is received as a by-product for different purposes as agricultural application and biogas production.

Keywords: Circular economy, energy reclamation, nutrient recovery, wastewater management

Received: 24 May 2021

Revised: 3 June 2021

Accepted: 8 July 2021

\section{Introduction}

In recent decades due to the rapid increase of resource use and urbanization, authorities are pushed to shift from traditional methods of resource use to circular economybased principles (BSI Group, 2017; Kakwani and Kalbar, 2020). Therefore, instead of regular use with further disposal now the main managing strategy aims for resource conservation more sustainably.

The circular economy (CE) concept in the water sector is gaining more attention as water-related problems cause more concerns, while most of the treatment facilities still utilize a linear approach of water management (take-make-use-dispose) (figure 1). There are several CE strategies, that can be used to reduce continuous input of fresh resources and generation of wastes (figure 2).

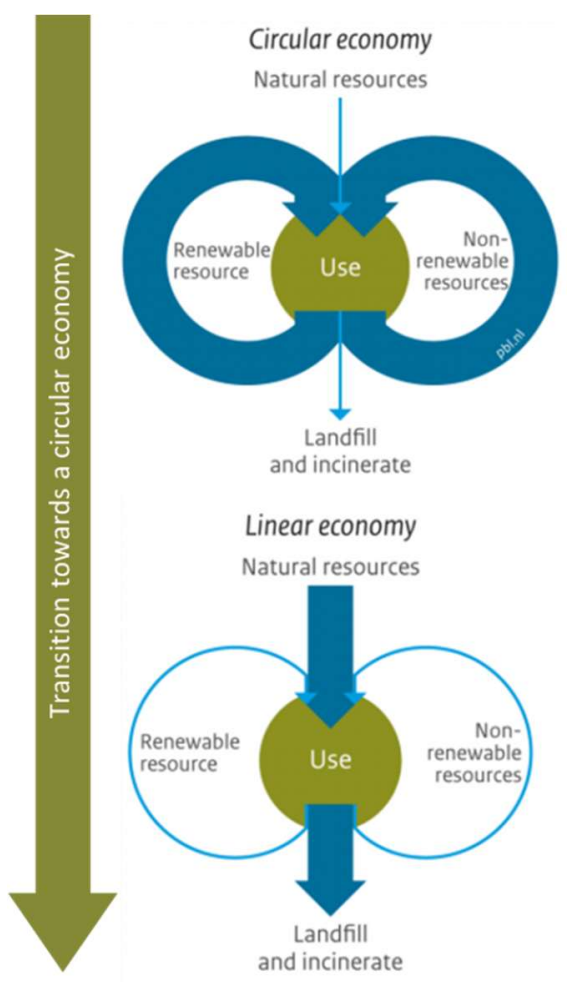

Fig.1. Linear vs. Circular economy (Potting et al., 2017) 


\begin{tabular}{|c|c|c|c|}
\hline \multirow{2}{*}{$\begin{array}{c}\text { Circular economy } \\
\text { approach }\end{array}$} & \multirow{3}{*}{ 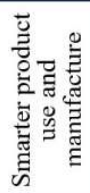 } & R0 & Refuse \\
\hline & & $\mathrm{R} 1$ & Rethink \\
\hline & & R2 & Reduce \\
\hline & \multirow{5}{*}{ 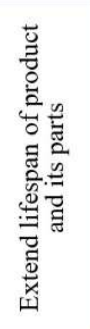 } & R3 & Re-use \\
\hline & & R4 & Repair \\
\hline & & R5 & Refurbish \\
\hline & & R6 & Remanufacture \\
\hline & & R7 & Repurpose \\
\hline & \multirow{2}{*}{ 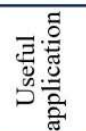 } & R8 & Recycle \\
\hline $\begin{array}{l}\text { Linear economy } \\
\text { approach }\end{array}$ & & R9 & Recover \\
\hline
\end{tabular}

Fig. 2. Circularity strategies (Potting et al., 2017)

All the strategies are ordered according to the level of circularity, where the higher circularity the longer resource stays in the product chain. This way environment will benefit as unextracted resources will be conserved.

\section{CE concept in wastewater}

\section{management}

Water is one of the most valuable resources that play an important role in agriculture, health care, different kinds of industry, and daily life.

According to WHO by 2025 at least half of the population will live in water-stressed areas, even now about $20 \%$ of people in the least developed countries do not have sufficient water, sanitation, and waste management services (WHO, 2021). There are 3 main prerequisites for water scarcity: physical (water lack in the dry and arid areas), economical (water is too expensive to transport or treat), and institutional (there are no adequate infrastructures available to ensure a regular supply) (UN-Water, 2021). Other upcoming problems such as climate change and increasing energy and water consumption add up to already complicated interrelationship between development and demand (UN-Water, 2021).

For a long time, wastewater was treated as waste, however, modern approaches of $\mathrm{CE}$ perceive wastewater as a valuable source of nutrients that can be utilized for agricultural purposes and energy recovery, which will make the treatment process more financially and environmentally sustainable (figure 3). This way treatment process should produce resources and by-products, that can be used in further processes avoiding waste generation (Leyva-Díaz et al., 2020).

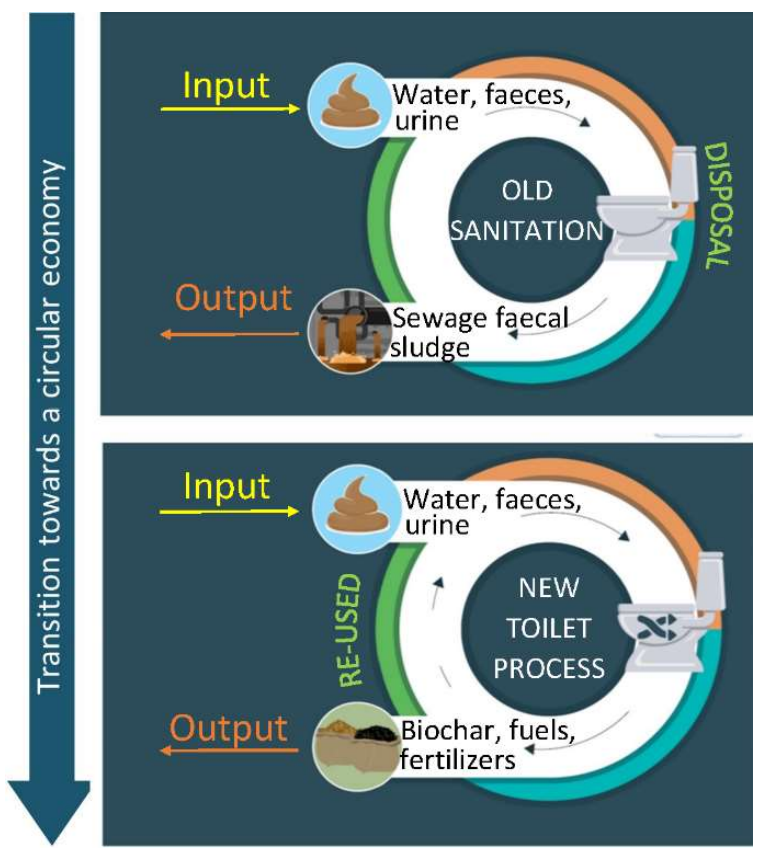

Fig.3. Sanitation circular economy (Zvimba, 2017).

\section{Biomembrane pilot plant}

A combination of moving bed biofilm reactor (MBBR) and membrane technology (MBR) is one of the solutions, that fit in the concept of circular economy, and it is a robust and mostly self-sustaining system that needs chemicals only during the membrane cleaning stage. Such installations can be used either as 
a replacement of municipal conventional systems or a smaller scale cluster-type system (where water treatment is performed for a cluster of up to around 100 houses).

Study set-up: The investigation took place in the Norwegian University of Life Sciences with co-financing by the European Union's ERASMUS ${ }^{+}$Project and under the support of Ecomotive AS.

Wastewater source: wastewater from the local dormitory in Ås, Norway that came as 2 separate lines of black and greywater. This way amount of nutrients in feed water can be regulated by the ratio of black to greywater (1:10 ratio was used).

Pilot plant characteristics: The pilot plant consists of 5 tanks: equalization, 2 subsequent MBBRs, membrane separation, and permeate tank. System was operated for 130 days and showed good performance with a gradual steady fouling rate (Dzihora, 2019b).

Membrane characteristics: 3 modules with $\mathrm{SiC}$ microfiltration (MF) membranes with a total filtration area, about $0.828 \mathrm{~m}^{2}$. Gross flux reached about $450 \mathrm{LMH}$ with theoretical gross capacity reaching $3 \mathrm{~m}^{3} /$ day. Each tank has a volume of $100 \mathrm{~L}$.
Treatment process: Water is pumped continuously into the equalization tank (EQ) (not shown on the principal scheme). Water enters the top of the container and mixes as falls. After that water undergoes biological treatment in 2 subsequent moving bed biofilm reactors (aerobic during the study and upgraded to anaerobic in the end). The system is connected to the ventilation to avoid the escape of the produced gasses. After some time, water enters the membrane separation chamber where it goes through the membranes into the permeate tank. At this stage some of the sludge is captured and returned to the biological stage, ensuring that there is enough biomass to perform efficient purification in MBBR and remove unnecessary fouling material from the separation chamber.

Excess sludge (biomass in MBBR was maintained around $5 \mathrm{mg} / \mathrm{L}$ ) is then collected for further processing. Depending on the chosen destination of sludge it should be accordingly processed. Usually, sludge undergoes one or a combination of followed methods: thickening, stabilization, dewatering, disposal.

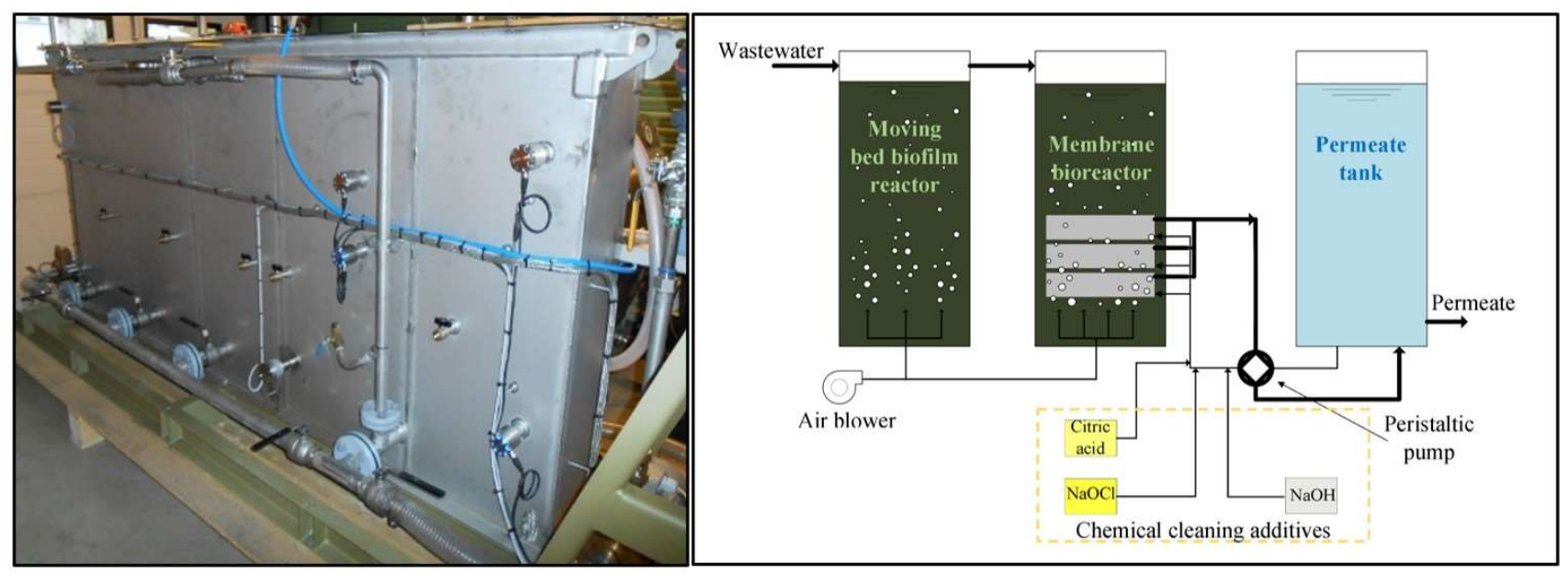

Fig.4. Biomembrane pilot plant

(Dzihora, 2019a) 
Products, by-products \& wastes: Sludge from MBBR tanks, potentially biogas in case of upgrading MBBR tank from aerobic to anaerobic, treated water (main parameters are shown in table 1), washing water (solutions of citric acid, chlorine with fouling particles that was washed away from the membranes).

Since on the current set-up, the only byproduct is sludge followed section will focus on sludge utilization only.

Table 1. System parameters and compared to standard requirements

\begin{tabular}{|c|c|c|c|c|c|c|c|}
\hline & Parameter & \multicolumn{2}{|c|}{ COD } & \multicolumn{2}{|c|}{ Turbidity } & \multicolumn{2}{|c|}{ SS } \\
\hline & Unit & \multicolumn{2}{|c|}{$\mathrm{mg} / \mathrm{L}$} & \multicolumn{2}{|c|}{ NTU } & \multicolumn{2}{|c|}{$\mathrm{mg} / \mathrm{L}$} \\
\hline & Val. type & $\max$ & avg. & $\max$ & avg. & $\max$ & avg. \\
\hline \multirow{3}{*}{$\begin{array}{l}\text { Pilot plant } \\
\text { parameters }\end{array}$} & Raw water & 342.0 & 205.7 & $\mathrm{~N} / \mathrm{A}$ & $\mathrm{N} / \mathrm{A}$ & 4.89 & 0.59 \\
\hline & Permeate & 61.2 & 33.6 & 1.80 & 0.44 & 0.14 & 0.01 \\
\hline & Reduction \% & $82.1 \%$ & $83.7 \%$ & N/A & N/A & $97.1 \%$ & $98.3 \%$ \\
\hline $\begin{array}{l}\text { Treatment } \\
\text { requirement }\end{array}$ & $\begin{array}{l}\text { EU Urban WW } \\
\text { treatment } \\
\text { Directive } \\
\text { (UWWRD)* }\end{array}$ & \multicolumn{2}{|c|}{$\begin{array}{l}125(75 \% \\
\text { reduction) }\end{array}$} & \multicolumn{2}{|c|}{ N/A } & \multicolumn{2}{|c|}{$\begin{array}{l}35(90 \% \\
\text { reduction) }\end{array}$} \\
\hline \multirow{3}{*}{$\begin{array}{l}\text { Requirement } \\
\text { for use for } \\
\text { agricultural } \\
\text { purposes }\end{array}$} & $\begin{array}{l}\text { US EP* } \\
\text { food crops }\end{array}$ & \multicolumn{2}{|c|}{$<20 * *$} & \multicolumn{2}{|c|}{$<2$} & \multicolumn{2}{|c|}{ N/A } \\
\hline & $\begin{array}{l}\text { US EPA* } \\
\text { Processed } \\
\text { food crops }\end{array}$ & \multicolumn{2}{|c|}{$<60 * *$} & \multicolumn{2}{|c|}{ N/A } & \multicolumn{2}{|c|}{$<30$} \\
\hline & $\begin{array}{l}\text { EU directive } \\
\text { all types of crops }\end{array}$ & \multicolumn{2}{|c|}{$<20 * *$} & \multicolumn{2}{|c|}{$<5$} & \multicolumn{2}{|c|}{$<10$} \\
\hline
\end{tabular}

* according to EU and US-EPA regulations (Schellenberg, 2020).

** considering that $\mathrm{BOD} / \mathrm{COD}$ ratio is average around 0.5 (TUHH, 2015).

\section{Water management (permeate)}

During the performance of the installation relatively steady effluent characteristics were recorded, even though raw water parameters varied to the great extent.

Permeate obtained after membrane cleaning has good quality parameters but depending on further usage of reclaimed water it might require further cleaning/disinfection or can be used right away. Reclaimed water can be utilized in the followed ways (World Bank, 2020; Zvimba, 2019):

- as potable water: (should be additionally treated before use) that can be directly supplied or blended with raw. There are possible challenges related to the human perception as it can be not accepted culturally and requires preliminary education so that people know that it is safe.

- as industrial or domestic non-potable: use onsite in the industries, for toilet flushing, garden watering, car washing, etc (might need extra treatment/disinfection if in contact with a people).

- for groundwater recharge.

- return to the surface water.

- recreational use.

According to the table 1 it can be concluded that permeate has met all the 
treatment requirement according to UWWRD and can be discharged in the water body. However, it also can be used for irrigation for food crops that are usually consumed processed, for decorative plants, or can be discharged and additionally treated in natural treatment systems as constructed wetland or infiltration pond system. In order to use it on food crops that consumed raw, or if use of water anyhow can influence human health, then it should additionally be treated to reduce COD, turbidity and TSS (while solids are providing surface area for microbes, those parameters can be associated with higher microbial contamination (Schellenberg, 2020)) with subsequent disinfection.

\section{Sustainable}

sludge

\section{management}

Sludge is a semi-solid mixture of components obtained from different stages of wastewater treatment. Usually, sludge use is very limited since it might contain a lot of different compounds that are not always safe to use on the land. One of the biggest issues are derived from the chemical precipitation stage of WW treatment, namely metals (salts of $\mathrm{Al}$ and $\mathrm{Fe}$ used as coagulants). In this case, because the sludge is obtained from the biological stage, it most likely will not contain metals in hight amounts (depends on source water) and after specific processing (to remove bacteria, parasites, viruses) it will be safe to use.

Sludge in its turn is a valuable resource that can be used for nutrients $(\mathrm{N}, \mathrm{P}, \mathrm{K})$ and energy recovery. However, depending on the feeding water benefit from sludge recycling will vary to a great extent: the more diluted feed water is - the fewer nutrients it contains (greywater and stormwater mostly do not have any nutrient or calorimetric value).

As for sludge processing, sludge can be processed in 2 ways (according to the linear and circular economy). Those methods are shown in table 2 .

Table 2. Possible uses of activated sludge

\begin{tabular}{|l|}
\hline \multicolumn{1}{|c|}{ Linear economy logic } \\
\hline - Landfill disposal \\
- Incineration \\
- Land spreading \\
\hline \multicolumn{1}{c|}{ Circular economy logic } \\
\hline - Land use \\
- Construction material \\
- The fuel source for the construction \\
- industry \\
- Granular sludge \\
- Incinas production \\
- Biochar production and energy recovery \\
\hline
\end{tabular}

\section{Possible challenges}

The water sector is facing constantly growing water demand and there is also a big gap in between the production of potable water and the need for it as well as generation and treatment of wastewater (in some countries up to $60 \%$ ) (Kakwani and Kalbar, 2020).

Technological challenges:

- Absence/non-reliability or selection difficulties of appropriate technology.

- Obsolete treatment systems, need of upgrade/replacement.

- Challenges related to collection and distribution systems.

- Net-negative wastewater treatment.

Economic challenges:

- High energy const.

- Low or no energy recovery.

- Reclaimed water is more expensive. 
- Additional transportation and distribution of reclaimed water.

\section{Governance challenges:}

- Lack of policies.

- Lack of experience, expertise, and skilled manpower.

- Implementation of innovative solutions will affect conventional processes changing them completely, which will require money and time.

Social:

- Lack of communication and coordination.

- Public acceptance that reclaimed water can be used again.

- Lack of knowledge about water scarcity and conservation.

\section{Conclusion}

A water crisis is one of the most disturbing issues of the modern world, but it can be solved if a more holistic and sustainable approach is used. From this paper, it is clear, that all new technologies should be planned in the way they generate by-products instead of wastes. Application of CE concepts in the water sector will give followed advantages:

- Water:

- Water can be treated to different quality levels for multipurpose use (for example for irrigation).

- Sludge:

$\circ$ Use as a fertilizer (with preliminary preparation or processing):

- Nutrient recovery.

- Soil state restoration.

- Carbon sequestration.

○ Energy recovery (for example syngas production during pyrolysis).

○ Use as adsorbent (after treatment and pyrolysis).
- Use as a material (in the dried processed state)

- Biogas:

○ Collection of gas during anaerobic digestion.

It is also should be mentioned that except all the listed above there are many financial (lower treatment price, increased product sales, etc), health care (improved water quality and food security, disease prevention, etc), and social (new job opportunities, sanitation management, etc) benefits (GRID-Arendal / Studio Atlantis, 2020).

For the pilot plant that was described in the paper due to the low production rate it is was decided for water to use it partially as wash water (for membrane cleaning) and partially as irrigation water for decorative plants located nearby otherwise it requires additional treatment and disinfection. Sludge due to the low amount can be after digestion and dewatering can be applied as a fertilizer on land.

\section{References}

1. BSI Group. Executive Briefing: $B S$ 8001-a Guide; London, UK.

2. Dzihora, Y. Combination of Moving Bed Biofilm Reactor and Membrane Bioreactor for Wastewater Treatment. In Modern trends in the development of water supply and sanitation; BSTU: Minsk, Belarus, 2019; pp 147-150.

3. Dzihora, Y. Combined Biomembrane Wastewater Treatment. In Proceedings of the Eighteenth International Scientific and Practical Conference: Resources of natural water of the Carpathian region. Problems of protection and rational use; Lviv Polytechnic National University: Lviv, Ukraine, 2019; Vol. 8, pp 117-118.

4. GRID-Arendal/Studio Atlantis. Drivers of the circular economy approach in wastewater management | GRID-Arendal https://www.grida.no/resources/13806 (accessed May 24, 2021).

5. Kakwani, N. S.; Kalbar, P. P. Review of Circular Economy in Urban Water Sector: Challenges and Opportunities in India. Journal of Environmental 
Management. Academic Press October 1, 2020, p 111010.

6. Leyva-Díaz, J. C.; Monteoliva-García, A.; Martín-Pascual, J.; Munio, M. M.; García-Mesa, J. J.; Poyatos, J. M. Moving Bed Biofilm Reactor as an Alternative Wastewater Treatment Process for Nutrient Removal and Recovery in the Circular Economy Model. Bioresource Technology. Elsevier Ltd March 1, 2020, p 122631.

https://doi.org/10.1016/j.biortech.2019.122631.

7. Potting, J.; Hekkert, M.; Worrell, E.; Hanemaaijer, A. Circular Economy: Measuring Innovation in the Product Chain; 2017.

8. Schellenberg, T.; Subramanian, V.; Ganeshan, G.; Tompkins, D.; Pradeep, R. Wastewater Discharge Standards in the Evolving Context of Urban Sustainability - The Case of India. Frontiers in Environmental Science. Frontiers Media S.A. April 17, 2020, p 30. https://doi.org/10.3389/fenvs.2020.00030.

9. Technische Universität Hamburg. Interrelationship between $\mathrm{BOD}, \mathrm{COD}$ and $\mathrm{TOC}$ https://doi.org/10.1016/j.jenvman.2020.111010.

http://cgi.tu-

harburg.de/ awwweb/wbt/emwater/lessons/lesson_a1/1 m_pg_1068.html (accessed Jul 4, 2021).

10. United Nations - Water. Water scarcity https://www.unwater.org/water-facts/scarcity/ (accessed May 24, 2021).

11. World Health Organisation. Drinking water https:/www.who.int/news-room/factsheets/detail/drinking-water (accessed May 24, 2021). https://doi.org/10.1177/027046768200200107.

12. World Bank. Wastewater: From Waste to Resource

https://www.worldbank.org/en/topic/water/publication/ wastewater-initiative (accessed May 24, 2021).

13. Zvimba, J. N.; Water Research Commission. Circular Economy Model for Water and Wastewater Management; 2019. 


\title{
БІОЛОГІЧНА ОБРОБКА СТІЧНИХ ВОД В КОНТЕКСТІ КРУГОВОЇ ЕКОНОМІКИ
}

\author{
Дзігора Ю.В. ${ }^{1,2}$, Столяренко Г.С. ${ }^{1}$ \\ ${ }^{1}$ Черкаський державний технологічний університет, Черкаси, Україна \\ ${ }^{2}$ Норвежзький університет природничих наук, Ос, Норвегія
}

\begin{abstract}
3 початком антропогенної епохи природа стикається все з більшою кількістю екологічних проблемам, кількість яких різко зросла в минулому столітті. За нинішніх темпів спожсивання ресурсів незабаром природа втратить здатність до самовідновлення. Щоб уникнути неминучих наслідків експлуатащії ресурсів, слід розробляти нові підходи у всіх сферах людського життя. Концепиї лінійної економіки, які використовувались тривалий час і базувались на використанні та управлінні кожним окремим ресурсом залежно від призначення ресурсу, вже не задовольняють вимог сучасного світу. Слід застосовувати більш иілісний підхід для подолання перешкод, з якими ми стикаємось зараз. Застосування концепџій кругової економіки для очисних споруд має великий потенціал для підвищення стійкості управління водними ресурсами. Ця стаття зосереджена на конщепиіях кругової економіки, що застосовуються для сучасної пілотної установки, що поєднує біологічну обробку та мембранне розділення, а також піднімає питання потенціального повномасштабного впровадження. Оскільки пілотна установка експлуатувалася без додавання хімічних речовин (окрім хімікатів для періодичного очищення мембран, щэо не потрапляє у вихідний продукт), ие полегшує використання надлишкового активованого мулу, що отримується у якості побічного продукту і може використовуватись для різних цілей таких я сільськогосподарське застосування (органічне добриво) та виробництво біогазу.
\end{abstract}

Ключові слова: кругова економіка, регенерачія енергії, відновлення поживних речовин, управління стічними водами 